\title{
Climate Change Awareness and Joint Decision to Adopt Agroforestry and Conservation Agriculture Practices in Zambia
}

\author{
Moses C. Tembo ${ }^{1}$, Elias Kuntashula ${ }^{2} \&$ Thomson Kalinda ${ }^{2}$ \\ ${ }^{1}$ The International Maize and Wheat Improvement Center (CIMMYT), Lusaka, Zambia \\ ${ }^{2}$ Department of Agricultural Economics \& Extension, University of Zambia, Lusaka, Zambia \\ Correspondence: Elias Kuntashula, Department of Agricultural Economics and Extension, University of Zambia, \\ Lusaka, Zambia. Tel: 260-9-77745-8335. E-mail: ekuntashula@unza.zm
}

\author{
Received: June 30, 2017 \\ Accepted: July 11, 2017 Online Published: July 30, 2017 \\ doi:10.5539/jsd.v10n4p107 \\ URL: https://doi.org/10.5539/jsd.v10n4p107
}

\begin{abstract}
Climate change is one of the biggest challenges that small holder farmers face in Sub-Saharan Africa, including Zambia. In response to this, various interventions such as Agroforestry (AF) and Conservation Agriculture (CA) have been promoted within the country so as to enhance uptake among farmers and ultimately mitigate climate change. However, the adoption rates of these technologies has been low. To understand the adoption process several adoption studies have focused on the effects of socio-economic and other institutional factors on adoption of the technologies. The direct link between small holder farmer's climate change awareness and the uptake of both $\mathrm{AF}$ and $\mathrm{CA}$ is an area that has received less attention among these studies. This paper estimates the effect of climate change awareness on the adoption of AF and CA, and establishes whether the adoption of the two technologies is jointly determined in Zambia. Data used emanated from the Indaba Agricultural Policy Research Institute (IAPRI) and University of Zambia (UNZA) Climate Change and Land Use Project that implemented a supplemental climate change survey in 2013 on Rural Agricultural Livelihood Survey (RALS 2012) panel sample of 1,231 households in six districts of Zambia. Results showed that the majority of farmers $(77.2 \%)$ were aware of climate change issues and their consequences on agriculture production and the environment. It was also observed that holding other factors constant, a farmer aware of climate change and its consequences was $6 \%$ more likely to adopt both $\mathrm{AF}$ and $\mathrm{CA}$ compared to those not aware. The decision to adopt $\mathrm{AF}$ and $\mathrm{CA}$ was found to be jointly determined by farmers. In addition to climate change awareness, the other factors affecting the joint decision to adopt the two technologies included gender, farmer group membership of the household head as well as ownership of radio sets and rippers. There is need therefore to deliberately increase climate change awareness among smallholder farmers and promote the simultaneous uptake of both $\mathrm{AF}$ and CA through the mass media and the provision of an environment that increases accessibility to tools that ease up the uptake of these technologies.
\end{abstract}

Keywords: agro forestry (AF), conservation agriculture (CA), climate change awareness, joint adoption, Zambia

\section{Introduction and Background}

In recent years, various studies have shown negative impacts climate change has had on agriculture in many countries (Valipour 2017, 2015, 2013; Valipour \& Montazar 2012; Valipour 2012; Valipour M., Mousavi, Valipour R \& Rezaei, 2012). In addition, the threats posed by climate change, environmental degradation and food insecurity has risen to the top of the developmental agenda in most Sub-Saharan African countries including Zambia. In the process, there have been rigorous programmes started by the government, agricultural based NGO's and other organizations to encourage the adoption of Climate Smart Agriculture (CSA) practices among small holder farmers to mitigate climate change, improve resilience and ultimately increase food security. Agroforestry (AF) and Conservation Agriculture (CA) are some of the few practices under CSA that can simultaneously mitigate climate change and also increase household food security. There have been a lot of programmes that have been developed and designed to encourage the adoption of both AF and CA by small holder farmers across Zambia and Sub-Saharan Africa but surprisingly adoption rates for the two technologies remain relatively low. For example, Ajayi (2007), estimated 20.6\% as the adoption rates of AF in Eastern Zambia where the technology has been vigorously promoted while Neubert et al. (2011) estimated that in 2007, only $10 \%$ of the farmers had embraced CA in Zambia. 
As a result of the low adoption rates, a number of studies (Ajayi et al., 2003, 2007; Arslan and Taylor 2009; Bellon and Taylor 1993; Franzel et al., 2004; Kabwe et al. 2010; Keil et al., 2005; Kwesiga et al., 2003; Opio 2001; Peterson 1999; Phiri et al., 2004; Smale, Just, and Leathers 1994) have been conducted with the broad objectives of determining the factors that affect adoption of AF and CA in Zambia. These studies have focused on the effects of socio-economic and other institutional factors on adoption of the technologies. In these studies, general awareness of $\mathrm{AF}$ and $\mathrm{CA}$ in promoting food security has in most cases been hypothesized as one of the determinants affecting adoption. The direct link between small holder farmer's climate change awareness and the uptake of both $\mathrm{AF}$ and $\mathrm{CA}$ is an area that has received less attention among the adoption studies. Furthermore, literature reviewed showed that the modeling of the adoption process of either AF or CA has been treated independently of each other. This is despite the two technologies being similar in terms of the expected outcomes. The possibility that the two technologies are being embraced in a joint decision adoption process since they are related is very high. Therefore, the objective of this study was two-fold: to investigate the effect of climate change awareness on $\mathrm{AF}$ and $\mathrm{CA}$ adoption, and to determine whether adoption of the two technologies by farmers is jointly determined.

The Food and Agriculture Organization [FAO] (2010), defines AF as land use systems and practices in which woody perennials are deliberately integrated with agricultural crops and/or livestock for a variety of benefits and services. The integration can be either in a spatial mixture (e.g. crops with trees) or in a temporal sequence (e.g. improved fallows, rotation). In Zambia, the Conservation Farming Unit (CFU) which is a specialized unit of the Zambia National Farmers Union (ZNFU), defines CA as an agriculture approach that involves planting and farming practices that include conversion from overall tillage to mechanized minimum tillage or zero tillage coupled with the retention of crop residues and practice of crop rotation (Conservation Farming Unit [CFU], 2007).

Different definitions of agroforestry and conservation agriculture adoption have been developed according to the technology under consideration (World Agro Forestry Center [ICRAF], 2004). According to Ajayi et al, (2007), adoption of $\mathrm{AF}$ is a complex process due to its various components and the many years it takes for the technology to be tested, modified and taken up by farmers. The authors further states that due to this, developing an exact definition of AF adoption proves to be challenging. Franzel et al. (2002) distinguished among 3 groups mainly "testers", "experimenters" and "adopters" while Ajayi et al. (2003) considered the uptake of AF technologies as a continuum and suggested that farmers be assigned positions in the continuum based on the level of uptake of the different components AF technology.

This complexity of adoption definition is not only unique to AF. According to Arslan et al. (2013), adoption of $\mathrm{CA}$ in Zambia tended to be incremental and partial. This means that farmers practiced both conventional farming and CA on different farm plots and increased the area allocated to CA from one season to the next. This was supported by a study that was conducted by Umar et al (2011) in which it was found that almost all farmers that were interviewed practiced both conventional and conservation farming on different plots. According to Sechrest et al. (1998) adoption is considered as a dynamic process while Rogers $(1983,2003)$ defines it as the implementation of already transferred knowledge about a technological innovation, and that adoption is the end product of the technology transfer process. Adoption occurs when one has decided to make full use of the new technology as a best course of action for addressing a need (Rogers, 2003). For purposes of this study, a farmer who has used at least one of the following common AF species promoted in Zambia; Faidherbia albida, Gliricidia Sepium, Sesbania Sesban and Tephrosia Vogelii to improve crop yields was considered as having adopted the technology. Furthermore, a farmer was considered as having adopted CA provided that they were practicing at least one of the following practices; minimum tillage, residue retention and crop rotation.

Various factors affect the adoption of both AF and CA. Iskander (2011) conducted a study in Indonesia and found that risk and uncertainty, lack of technical knowledge, shortage of labour, and lack of access to seed were the main factors that constrained farmers from taking up AF. In another study done in Pakistan, Muhammad et al., (2011), found that farmer's perceptions about AF, level of income as well as level of education positively contributed towards the adoption of AF. Furthermore, Mwase et al., (2015) conducted a study to determine the factors that affected the adoption of AF in Africa. They found that high initial costs of agroforestry practices, low extension services as well as the unavailability of AF germ plasm were significant in determining adoption. In another study done by Jamala et al., (2013) in Nigeria, it was found that farmers lack of knowledge on AF, limited land and lack of AF were the main constraints of AF adoption.

In Latin America, several studies (Ekboir, 2003; Knowler and Bradshaw 2007; Wall 2007; Friedrich and Kassam 2009; Erenstein et al., 2012)found that limited access to credit, farmers' inability to take risks, short term priorities, land tenure, residue tradeoffs as well as poor extension services which lead to low CA knowledge were 
the main determinants of CA adoption. In Zimbabwe, Mavunganidze et al., (2013) found that age, formal education, access to extension services, labour, animal draught power availability and the size of the land were important in determining the adoption of CA by farmers. Mankwe (2013), observed that gender, level of income of farmers and land ownership affected the adoption of CA in Tanzania.

The review of adoption studies on $\mathrm{AF}$ and $\mathrm{CA}$ show that indeed a lot has been studied with regards to the factors and constraints affecting the uptake of the two technologies. However what is also coming out more explicitly is that the studies have lacked the inclusion of the influence of climate change awareness on the adoption process, and that the technologies' adoption process have been studied in isolation of each other despite sharing several common traits as climate smart technologies. Furthermore, the major weakness of past studies is that the modeling of the adoption process of either $\mathrm{AF}$ or $\mathrm{CA}$ has been treated independently of each other. The possibility that the two technologies are being embraced in a joint decision adoption process since they are related is very high. Thus as a contribution to literature on adoption studies, we assess in this study, how the influence of climate change affects the adoption of AF and CA. Using the bi-probit regression model, we further test whether the two technologies are adopted in a joint decision behavioral process by small holder farmers in Zambia. The study affirms that farmers' knowledge of climate change and its consequences increases the probability of adopting the two technologies. The study also reveals that the decision to adopt either AF or CA is jointly determined. The rest of the paper is structured as follows: the methodology giving data sources, conceptual and analytical frameworks immediately follow this introduction. This is followed by the results and discussion sections. Finally conclusions are drawn based on the findings of the study.

\section{Methodology}

\subsection{Data and Data Sources}

Data used in this study was collected in 2013 under the Indaba Agricultural Policy Research Institute (IAPRI)/University of Zambia Climate Change Land Use project. The 1,231 households in the sample were selected from a nationally representative sample of the Rural Agricultural Livelihood Survey of 2012 (RALS 2012) conducted by the Zambia Central Statistics Office (CSO) and Indaba Agricultural Policy Research Institute (IAPRI). The IAPRI and University of Zambia (UNZA) Climate Change supplemental survey of 2013, the basis of the data used in this study sought to assess the levels of climate change awareness by the farmers and what mitigation and adaptation measures they were putting in place. The supplemental survey used a structured questionnaire that was implemented to the 1,231 household heads. The questionnaire took about $40-60$ minutes to administer (Kuntashula et al., 2014). The questionnaire captured the following broad areas of interest; perceptions of climate change, mitigation and adaptation measures, crops and livestock husbandry practices and socioeconomic characteristics of the farmers.

\subsection{Conceptual Framework}

The theory of consumer utility maximization was the main concept upon which this study was based. The choice decision of a given farm household was considered to be discrete so that the choice variable was qualitative. For any rational farm household, if each conservation practice ( $\mathrm{AF}$ and/or $\mathrm{CA}$ ) was seen as a possible adoption, then such a farm household was expected to choose the conservation practice that maximized their utility. According to Greene (2008), the aforesaid approach was based on the linear random utility assumption and is normally expressed as follows:

$$
\left\{\begin{array}{l}
U_{i 0}=x_{i}^{\prime} \beta_{i 0}+e_{i 0} \\
U_{i 1}=x_{i}^{\prime} \beta_{i 1}+e_{i 1}
\end{array}\right.
$$

Where;

$U_{i j}$ is a measure of utility derived by farm household $i$ from choosing alternative $j$ (with the decision not to adopt $\mathrm{AF}$ and CA being $U_{i 0}$ while that to adopt is denoted by $\left.U_{i 1}\right), x_{j}$ is a vector of characteristics specific to farm household $i$ as well as attributes associated with alternative $j$ and specific to the $i^{\text {th }}$ farm household, $\beta$ is a vector of unknown parameters, $e_{i j}$ is the random disturbance associated with the choice of alternatives $j$ by farm household $i$.

The probability that farm household $i$ chooses a particular alternative (i.e $\left.Y_{i}=1\right)$ versus another (i.e $\left.Y_{i}=0\right)$ is associated with the probability distribution of the error differences in the expected utilities from the choices and 
given by:

$$
P_{i}=\operatorname{prob}\left(Y_{i}=1 \mid x\right)=\operatorname{prob}\left(y_{i}^{*}>0 \mid x\right)=\operatorname{prob}\left[e_{i}>-x_{i}^{\prime} \beta \mid x\right]=\mathrm{F}\left(x^{\prime} \beta\right)
$$

From the above stated equation, $\mathrm{F}$ is the cumulative distribution function of $e_{i}\left(=e_{i 1^{-}} e_{i 0}\right)$ evaluated at $x_{i}^{\prime} \beta$, and $y_{i}^{*}\left(=U_{i 1}-U_{i 0}\right)$ is a latent variable, since it is unobservable, and is linked to $Y_{i}$, the observed binary variable, through the relation below:

$$
Y_{i}= \begin{cases}1 & \text { if } y_{i}^{*}>0 \\ 0 & \text { otherwise }\end{cases}
$$

The specification of a model to describe the relation between the probability of choosing an alternative and the explanatory variables is dependent on the assumption made regarding the distribution of the error term. Because this is a non-linear model, the effect of the explanatory variable is measured in terms of marginal effect which is the partial change in the probability of the outcome variable as a result of a change in the explanatory variable.

If the error term in the utility model is assumed to be normally distributed, then the analysis can be conducted using univariate or bivariate probit models (Green, 2008).

There are various explanatory variables that can affect the adoption of AF and/or CA within the realm of the conceptual framework. These variables are discussed below under five broad categories which include characteristics of the farm household head and the household, assets owned, information access and institutional factors as well as geographical factors.

\subsubsection{Farmer and Household Characteristics}

Household heads are the final decision makers who may decide on adopting AF and CA either singularly or simultaneously at the farm. The age of the household head is likely to influence adoption of these technologies. Younger farmers may be more innovative and have lower risk aversion behavior but they may also have less farming experience hence the relationship between age and adoption of technologies may be ambiguous. Other farmer and household characteristics such as gender, marital status and level of education are also expected to affect the decision to adopt either adopt $\mathrm{AF}$ and $\mathrm{CA}$ in a singular or as a joint decision adoption process. Female headed households may respond less favourably to adoption of technologies than male headed households due to wealth differences (Ajayi et al. 2003). However, some female heads are enthusiastic enough and more willing to try out technologies. Thus we expect gender of the household head to have an ambiguous effect on adoption of $\mathrm{AF}$ and/or CA. Divorced household heads might have fewer resources for adopting technologies such as AF and CA. However, the divorced household heads could also avoid bureaucratic tendencies of asking their partners (had they been married) in reaching a decision to adopt such technologies. The same applies to single and widowed household heads. Thus marital status of household heads is expected to have an ambiguous effect on adoption of AF and CA. Some educated households would be conservative to adopt AF and CA jointly while others would be more willing to adopt the technologies in a joint decision process so as to maximize the benefits. The level of education of the household head therefore, is also expected to either enhance or discourage adoption. Since both AF and CA are labour intensive, household's labour availability in terms of household size and ability to use hired and draught power, is expected to positively affect the farm household's decision to adopt the technologies either in a single or joint technology adoption process.

\subsubsection{Assets Owned}

In rural Zambia like most developing countries, the level of poverty affects production activities. Assets such as farm sizes, radios, televisions, mobile phones, access to credit etc., are expected to enhance adoption of AF and $\mathrm{CA}$ and are used in various models as indicators of wealthy. These variables provide production services and are expected to increase the likelihood of adoption for a given household.

\subsubsection{Information Access and Institutional Factors}

Literature evidence shows that other factors such as access to information and agricultural groups affect adoption of agricultural technologies. Farm households that have such access to these social capital are expected to be more likely to adopt AF and CA than their counterparts who do not have access. This is because access to information and groups provides vital farming information (Nyambose and Jumbe, 2013).

\subsubsection{Geographical Factors}

The influence of regions were the households came from could also influence adoption of the technologies. For example households located in districts found in low rainfall agro ecological regions I and II are more likely to adopt CA than those located in high rainfall areas in agro ecological region III (CFU, 2007). This is mainly due 
to the reason that in the low rainfall areas CA is used as a means of conserving water during dry spells. Finally, at the core of this study was farmer awareness of climate change and its consequences. The probability of adopting both $\mathrm{AF}$ and $\mathrm{CA}$ was hypothesized to increase with farmer knowledge on climate change. All these variables were considered in the estimation of the bi-probit model whose discussion is given in table 1 .

Table 1. Definitions of variables used in the bi-probit models

\begin{tabular}{lll}
\hline & & Expected Effect \\
Variable & Definition/codes & $\begin{array}{l}\text { Joint } \\
\text { on Adoption of AF } \\
\end{array}$ \\
& & and CA \\
\hline
\end{tabular}

\section{Dependent Variables}

Adoption of AF

Dummy $=1$ if household adopted AF, 0 otherwise

Adoption of CA

Dummy $=1$ if household adopted CA, 0 otherwise

\section{Explanatory Variables}

\section{Farmer and Farm Factors}

Age

Gender of household head

Marital status of household head

Education level of household head

Primary education

Secondary education

Tertiary education

Household size

Farm size

Area planted

Climate change awareness

Conservation farming advise

Labour hire

Animal labour

\section{Information Access and Institutional Factors}

Access to credit

Access to extension information

Agricultural group membership

Out-grower scheme membership

\section{Assets Owned}

Ownership of a ripper

Ownership of radio set

Ownership of mobile phone

Ownership of television set

\section{Geographical factors}

Choma district

Sinazongwe district

Serenje district

Mpika district

Nyimba district
Age of household head in years

$+/-$

1 if household head is male, 0 otherwise

1 if married, 0 otherwise

$+/-$

$+/-$

Primary education ( $=1$ if attended, 0 otherwise)

$+/-$

Secondary education ( $=1$ if attended, 0 otherwise)

Tertiary education ( $=1$ if attended, 0 otherwise)

Number of household members

Size of farm in hectares

Size of area planted in hectares

Climate change ( $=1$ if aware, 0 otherwise)

Conservation farming advise ( $=1$ if received, 0 otherwise)

Hired labour ( $1=$ if yes, 0 otherwise)

Animal labour ( $1=$ if yes, 0 otherwise)

Accessed credit ( $=1$ if yes, 0 otherwise)

Access to extension information ( $=1$ if yes, 0 otherwise)

Agricultural group ( $=1$ if yes, 0 otherwise)

Out-grower scheme ( $=1$ if yes, 0 otherwise)

Owns ripper ( $=1$ if yes, 0 otherwise)

Owns radio ( $=1$ if yes, 0 otherwise)

Owns mobile phone ( 1 if yes, 0 otherwise)

Owns television set ( 1 if yes, 0 otherwise)

Located in Choma ( $=1$ if yes, 0 otherwise)

Located in Sinazongwe ( $=1$ if yes, 0 otherwise)

Located in Serenje ( $=1$ if yes, 0 otherwise)

Located in Mpika ( $=1$ if yes, 0 otherwise)

Located in Nyimba ( $=1$ if yes, 0 otherwise) 


\subsection{Analytical Framework}

\subsubsection{The bi-Probit Regression Model}

This study used the bivariate probit model since the required analysis is based on categorical dependent variables (i.e. either farmer has jointly adopted $\mathrm{AF}$ and $\mathrm{CA}$ or not).

\subsubsection{Specification of the Model}

The probability of the adoption of AF and CA technologies is modeled as a function of certain characteristics of the small holder farmers. The decision by a farmer on whether to adopt the AF and CA technologies or not is hypothesized to be influenced by various factors which include age, and education level of household heads, the size of the household, previous training in $\mathrm{AF}$ and $\mathrm{CA}$, the wealth level of the household, the land tenure systems, access to farming inputs such as inorganic fertilizers, as well as how averse the household head is to risk. In addition, climate change awareness which could also affect this decision, was included among the independent variables. In the aforesaid model, the basic assumption is that farmers make adoption decisions about AF and CA jointly. This assumption allows for the testing of this joint adoption decision making process. A single equation approach to determine whether AF and CA adoption is jointly done is subject to simultaneity bias. The bivariate probit model, which is a natural extension of the probit model, is used to control the simultaneity problem in the joint decision process as suggested by Maddala (1983). The structural form of the bi-variate probit model can be written as follows:

$$
\begin{aligned}
& A F_{h t}^{*}=\alpha_{1} C A_{h t}^{*}+\beta_{1}^{\prime} Z_{h t}+\mu_{h t}^{1} A F_{h t}=1\left(\text { if } A F_{h t}^{*}>0,0 \text { otherwise }\right) \\
& C A_{h t}^{*}=\alpha_{2} A F_{h t}^{*}+\beta_{2}^{\prime} Z_{h t}+\mu_{h t}^{2} C A_{h t}=1\left(\text { if } C A_{h t}^{*}>0,0 \text { otherwise }\right)
\end{aligned}
$$

$\mathrm{E}\left(\mu_{h t}^{1}\right)=E\left(\mu_{h t}^{2}\right)=0$, and $\operatorname{Var}\left(\mu_{h t}^{1}\right)=\operatorname{Var}\left(\mu_{h t}^{2}\right)=1$ and $\operatorname{Cov}\left(\mu_{h t}^{1}, \mu_{h t}^{2}\right)=\rho$

Where;

$A F_{h t}^{*}$ : Agroforestry adoption latent dependent variable,

$C A_{h t}^{*}:$ Conservation Agriculture adoption latent dependent variable,

$Z_{h t}:$ Vector of dependent variables that affect adoption,

$$
\mu_{h t}^{1}, \mu_{h t}^{2} \text { Random errors }
$$

The model has the following characteristics: the first is that the dependent variables are binary; the second is that the binary dependent variable of first equation is entered as covariate in the second equation and vice versa; the third is that the unobserved heterogeneities of the two decisions are assumed to be correlated. These models can be estimated applying the two stage bivariate approach proposed by Maddala (1983), which is considered as consistent and efficient estimates. The reduced form of the model is:

$$
\begin{gathered}
A F_{h t}=\delta_{1}^{\prime} \mathrm{Z}+v_{1} \\
C A_{h t}=\delta_{2}^{\prime} \mathrm{Z}+v_{2} \\
{\left[v_{1}, v_{2}\right] \sim \operatorname{BVN}\left[(0,0), \pi_{1}^{2}, \pi_{2}^{2}, \Phi\right]}
\end{gathered}
$$

Where,

$Z$ : vector of exogenous variables,

$\pi_{i}:$ Standard deviation,

$v_{1} v_{2}:$ Random error terms,

$\Phi$ : Correlation between the error terms.

The predicted values from these two equations applying probit models are used for the bivariate model. The coefficients of discrete choice models like logit, probit, and bivariate probit may simply refer to the probability associated to dependent variables and analysis of these coefficients as a direct response may give misleading results. These parameters need to be transformed to yield estimates of the marginal effects, which are referred to the change in predicted probability associated with changes in the explanatory variables. Greene (2008) calculated marginal effects in a bivariate probit model. According to Greene (2008), the calculation of the bivariate probit model is based on whether or not $\rho$ is significant. If a Wald test shows thatpis significant, then both $\mathrm{AF}$ and $\mathrm{CA}$ adoption are endogenous processes. If $\rho$ is not significant, then no endogeneity bias is present and both equations can be estimated separately as binomial probits.

Furthermore, Greene (2008) presented four cases of the bivariate probabilities which are presented as follows:

$$
\operatorname{Prob}[i A F=1, i C A=1]=B V N\left(\beta_{1}^{\prime} z_{1}+\alpha_{1}, \beta_{2}^{\prime} z_{2}+\alpha_{2}, \rho\right),
$$


Where BVN is the bivariate normal cumulative distribution function. Other probabilities can be constructed with same analogous;

$$
\begin{gathered}
\operatorname{Prob}[A F=0, C A=1]=B V N\left(-\beta_{1}^{\prime} z_{1}-\alpha_{1}, \beta_{2}^{\prime} z_{2}, \rho\right) ; \\
\operatorname{Prob}[A F=1, C A=0]=B V N\left(\beta_{1}^{\prime} z_{1}, \beta_{2}^{\prime} z_{2},-\rho\right) ; \\
\operatorname{Prob}[A F=0, C A=0]=B V N\left(-\beta_{1}^{\prime} z_{1},-\beta_{2}^{\prime} z_{2}, \rho\right) ;
\end{gathered}
$$

The marginal effects in a binary probit model can be computed as follows:

$$
\mathrm{E}\left[\mathrm{AF} / Z_{1}\right]=\Phi\left(\beta^{\prime} Z_{1}\right)=\operatorname{Prob}[\mathrm{AF}=1]
$$

And for a continuous variable such as $x_{i}$, it is as follows;

$$
\frac{\partial E\left(\frac{A F}{Z_{1}}\right)}{\partial x_{i}}=\partial \Phi\left(\beta^{\prime} Z_{1}\right) / \partial x_{i}=\Phi\left(\beta^{\prime} Z_{1}\right) * \beta_{x}
$$

Where;

$\Phi($.$) ; is the density function of the standard normal distribution,$

$\beta_{x} ;$ is the coefficient on variable $\mathrm{x}$.

In a situation where the variable $x_{i}$ is binary, the above equation can be written as;

$$
\frac{\partial E\left(\frac{A F}{Z_{1}}\right)}{\partial x_{i}}=\mathrm{E}\left[\mathrm{AF} / Z_{1} x=1\right]-\mathrm{E}\left[\mathrm{AF} / Z_{1} x=0\right]
$$

Thus, the marginal effects calculated using the above equations are used to interpret the bi-probit model analysis results.

\section{Results and Discussion}

\subsection{Descriptive Statistics}

Table 2 depicts descriptive statistics that were used in this study. The table has five major columns describing the total sample, adopters and non-adopters of both AF as well as CA. Under each column are the variable means and their respective standard deviations for the total sample, adopters and non-adopters of both AF and CA. Adoption of both $\mathrm{AF}$ and $\mathrm{CA}$ were the dependent variables and both were equal to 1 if a particular household adopted $\mathrm{AF}$ and $\mathrm{CA}$ and 0 otherwise. The independent variables were farmer and farm characteristics, information access and institutional factors, assets owned as well as geographical factors.

Results indicated that the overall adoption rates of AF and CA were $12.9 \%$ and $30.3 \%$ respectively. Almost $90 \%$ of the households who adopted $\mathrm{AF}$ were male headed while the remainder were female. For those practicing $\mathrm{CA}$, $83.1 \%$ were male headed. This could be attributed to the reason that starting up of AF nurseries and subsequent transplanting as well as creation of basins under CA are labor intensive and thus most females avoid taking up both AF and CA technologies. The age of the respondents ranged from 20 years to 94 years. The average age of the household head was 46.3 years while for AF and CA adopters it was 45 and 46.7 years respectively. For household heads who had not adopted both AF and CA, the average age was about 46.6 and 46.1 years respectively. Results also showed that $86.4 \%$ of the household heads attended school. Of those who attended school, $57.4 \%$ managed only to attend primary education while $26.6 \%$ attended secondary level of education. However, only $2.5 \%$ of respondents managed to attend tertiary education and these could be attributed to the low access to tertiary education facilities in most parts of rural Zambia. It was also observed that the number of people in these farm households ranged from 1 to 18 members and the average size of the household was 6.1 for the total sample. On the other hand, the average household size for AF adopters and non-adopters was 6.02 and 6.1 respectively. For CA adopters, the average household size was 6.06 while it was 6.09 for non-CA adopters. The overall average household farm size was 2.97 hectares while it was 3.64 and 2.87 hectares for AF adopters and non-adopters respectively. The average household farm size was 3.1 and 2.9 hectares for CA adopters and non-adopters respectively. The observed results on land holdings supported findings in other studies that show that those with less land generally do not take up new technologies (Rogers, 2003). Further analysis of the data revealed that $77.2 \%$ or 950 of the farmers were aware of climate change issues and their consequences on agriculture production and the environment while $22.8 \%$ or 281 were not aware. The high levels of awareness could be explained by the many radio and television climate changes messages that farmers receive. In addition, $\mathrm{AF}$ adoption rates among farmers aware about climate change issues and their consequences and those that were not were $14.2 \%$ and $7.1 \%$ respectively. Furthermore, CA adoption rates among farmers aware about climate change issues and their consequences and those that were not were $33.9 \%$ and $18.1 \%$ respectively. The adoption 
rates of both technologies were higher among famers aware of climate change than those not due to the fact that information on environmental risks leads to farmers finding ways of adapting and/or mitigating against such.

Table 2. Social economic and farm characteristics

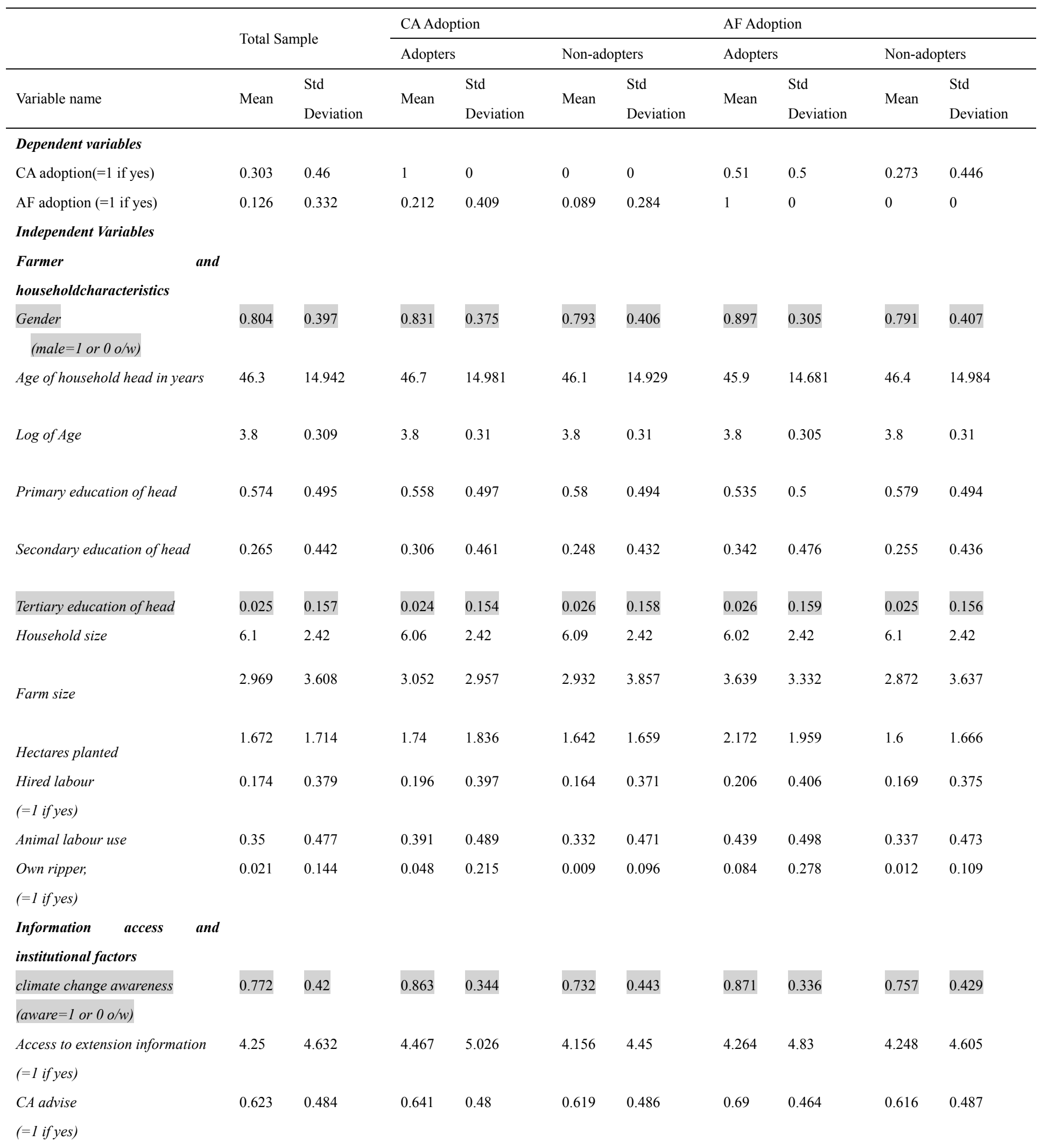




\begin{tabular}{|c|c|c|c|c|c|c|c|c|c|c|}
\hline \multirow[b]{3}{*}{ Variable name } & \multirow{2}{*}{\multicolumn{2}{|c|}{ Total Sample }} & \multicolumn{4}{|c|}{ CA Adoption } & \multicolumn{4}{|c|}{ AF Adoption } \\
\hline & & & \multicolumn{2}{|c|}{ Adopters } & \multicolumn{2}{|c|}{ Non-adopters } & \multicolumn{2}{|c|}{ Adopters } & \multicolumn{2}{|c|}{ Non-adopters } \\
\hline & Mean & $\begin{array}{l}\text { Std } \\
\text { Deviation }\end{array}$ & Mean & $\begin{array}{l}\text { Std } \\
\text { Deviation }\end{array}$ & Mean & $\begin{array}{l}\text { Std } \\
\text { Deviation }\end{array}$ & Mean & $\begin{array}{l}\text { Std } \\
\text { Deviation }\end{array}$ & Mean & $\begin{array}{l}\text { Std } \\
\text { Deviation }\end{array}$ \\
\hline \multicolumn{11}{|l|}{ Dependent variables } \\
\hline CA adoption(=1 if yes) & 0.303 & 0.46 & 1 & 0 & 0 & 0 & 0.51 & 0.5 & 0.273 & 0.446 \\
\hline $\mathrm{AF}$ adoption $(=1$ if yes) & 0.126 & 0.332 & 0.212 & 0.409 & 0.089 & 0.284 & 1 & 0 & 0 & 0 \\
\hline $\begin{array}{l}\text { Access to credit } \\
(=1 \text { if yes })\end{array}$ & 0.141 & 0.349 & 0.142 & 0.35 & 0.141 & 0.348 & 0.187 & 0.391 & 0.135 & 0.342 \\
\hline $\begin{array}{l}\text { Group membership } \\
(=1 \text { if yes })\end{array}$ & 0.452 & 0.498 & 0.525 & 0.5 & 0.421 & 0.494 & 0.594 & 0.493 & 0.432 & 0.496 \\
\hline $\begin{array}{l}\text { Out-grower scheme member } \\
(=1 \text { if yes) }\end{array}$ & 1.898 & 0.302 & 1.898 & 0.303 & 1.899 & 0.302 & 1.903 & 0.297 & 1.898 & 0.303 \\
\hline Geographical factors & & & & & & & & & & \\
\hline $\begin{array}{l}\text { Choma } \\
\text { (=1 if farmer located in distric }\end{array}$ & 0.123 & 0.329 & 0.15 & 0.356 & 0.112 & 0.315 & 0.155 & 0.363 & 0.119 & 0.324 \\
\hline $\begin{array}{l}\text { Sinazongwe } \\
(=1 \text { if farmer located in distric }\end{array}$ & 0.097 & 0.297 & 0.097 & 0.296 & 0.098 & 0.297 & 0.123 & 0.329 & 0.094 & 0.292 \\
\hline $\begin{array}{l}\text { Serenje } \\
(=1 \text { if farmer located in distric }\end{array}$ & 0.115 & 0.32 & 0.113 & 0.317 & 0.117 & 0.321 & 0.194 & 0.396 & 0.104 & 0.306 \\
\hline $\begin{array}{l}\text { Mpika } \\
(=1 \text { if farmer located in distric }\end{array}$ & 0.179 & 0.383 & 0.265 & 0.442 & 0.141 & 0.348 & 0.019 & 0.138 & 0.202 & 0.401 \\
\hline $\begin{array}{l}\text { Nyimba } \\
(=1 \text { if farmer located in distric }\end{array}$ & 0.232 & 0.422 & 0.182 & 0.387 & 0.253 & 0.435 & 0.2 & 0.401 & 0.236 & 0.245 \\
\hline Sample size & 1,231 & & 372 & & 858 & & 155 & & 1,076 & \\
\hline
\end{tabular}

Source: (IAPRI/UNZA Climate Change and Land Use Survey (2013) Data

\subsubsection{Empirical Results}

Further analysis of the data was conducted in order to empirically determine whether the adoption of AF and CA technologies was a joint decision. This was achieved using the bi-probit regression model. A Likelihood Ratio (LR) test of $\rho=0$ at $90 \%$ confidence level suggested that the adoption decisions about AF and CA were not independent (highlighted in Table 3). This could imply that both decisions were affected by the same unobservable heterogeneities and that the decisions were determined jointly. It can thus be observed that the use of the bi-probit regression model as opposed to other models allowed this study to determine the joint adoption decision among farmers without being subjected to the simultaneity bias problem. It further allowed the study to produce consistent and efficient estimates.

\subsubsection{Determinants of AF and CA Adoption}

There are various factors that were hypothesized to affect adoption of both AF and CA. Included to this list of factors was awareness of climate change and its consequences. This was done to assess the first objective of this study which was to determine whether climate change awareness affected adoption of AF and CA. In order to achieve this, a bi-probit regression model was used with climate change awareness being one of the independent variables. Model diagnostics were performed to check for possible model specification errors. The Wald Chi square statistic equaled $120.68(\mathrm{Prob}>\mathrm{Chi} 2)=0.000)$. This indicated that the hypothesis that all coefficients were equal to zero could be rejected at $1 \%$ significance level and thus the model fitted well. The variable climate change awareness was significant at $1 \%$ level of significance in the model. Climate change awareness and its consequences was found to have had a positive effect on the adoption of AF and CA technologies singularly as well as when the adoption process was jointly decided (Table 3 ). 
Table 3 also show other results on factors affecting the adoption of the two technologies. Holding other factors constant, male headed households than the female headed households were about $3 \%$ more likely to adopt $\mathrm{AF}$ and CA simultaneously. This is could mainly be because practices such as AF and CA are mainly adopted by males due to the amount of labour involved in raising nurseries for the trees and digging basins, transplanting trees into the field and the weekly watering of the plants in the field.

In addition, belonging to a farmer group raised the chances of adopting AF and CA together by $2 \%$. This could be as a result of the influence of other group members who have also adopted the technologies before and also the information received about such technologies during group meetings. In addition, analysis of the data showed that farmers who owned radio sets were more likely to jointly take up AF and CA than those that did not own the aforementioned asset. This could be attributed to the fact that radio sets are important assets through which farmers received information with regards to taking up $\mathrm{AF}$ and $\mathrm{CA}$ as well as other farm technologies.

Further analysis of the data also revealed that farmers who owned rippers were $13.5 \%$ more likely to jointly take up both $\mathrm{AF}$ and $\mathrm{CA}$ in comparison to those that did not own rippers. This could have been as a result of the ripper being an important implement used in minimum tillage which is one of the practices under CA. Furthermore, during analysis, spatial differences in the data were controlled for by the generation of dummy variables for the respective districts from which the households were sampled. Serenje and Mpika districts were significant at 5\% confidence level in determining the joint adoption of AF and CA. A household being located in Serenje than Petauke increased the probability of the farmer jointly adopting AF and CA by $3.5 \%$. In addition, being located in Mpika than Petauke reduced the probability of a farmer jointly adopting AF and CA by $4.5 \%$. These results could be explained by the fact that the Central Province of Zambia has been one of the areas in which both AF and CA projects have been implemented at a large scale than in Muchinga Province where Mpika is located. As a result farmers in Serenje (Central Province) were more likely to take up both practices as opposed to those farmers found in Mpika (highlighted in table 3).

Table 3. Determinants of CA and AF adoption decisions

\begin{tabular}{|c|c|c|c|c|c|}
\hline \multirow[t]{2}{*}{ Variable } & \multicolumn{2}{|c|}{ Conservation Agriculture } & \multicolumn{2}{|c|}{$\underline{\text { Agroforestry Adoption }}$} & \multirow{2}{*}{$\frac{\text { Joint Adoption }}{\text { Marginal effect }}$} \\
\hline & Coefficients & Marginal effect & Coefficients & Marginal effect & \\
\hline \multicolumn{6}{|c|}{ Farmer and household characteristics } \\
\hline \multirow[t]{2}{*}{ Gender } & 0.0525 & 0.0175 & $0.298 * *$ & $0.0568^{* *}$ & $0.0263 *$ \\
\hline & $(0.107)$ & $(0.0355)$ & $(0.148)$ & $(0.0282)$ & $(0.0140)$ \\
\hline \multirow[t]{2}{*}{ Age } & 0.00290 & 0.000965 & -0.000195 & $-3.71 e-05$ & $9.40 \mathrm{e}-05$ \\
\hline & $(0.00274)$ & $(0.000910)$ & $(0.00347)$ & $(0.000660)$ & $(0.000332)$ \\
\hline \multirow[t]{2}{*}{ Out-grower scheme membership } & -0.143 & -0.0474 & $0.477^{*}$ & $0.0909^{*}$ & 0.0325 \\
\hline & $(0.231)$ & $(0.0768)$ & $(0.253)$ & $(0.0481)$ & $(0.0253)$ \\
\hline \multirow[t]{2}{*}{ Primary education } & 0.0759 & 0.0252 & 0.0385 & 0.00734 & 0.00752 \\
\hline & $(0.123)$ & $(0.0407)$ & $(0.159)$ & $(0.0304)$ & $(0.0152)$ \\
\hline \multirow[t]{2}{*}{ Secondary education } & 0.183 & 0.0607 & 0.110 & 0.0209 & 0.0179 \\
\hline & $(0.143)$ & $(0.0474)$ & $(0.182)$ & $(0.0346)$ & $(0.0174)$ \\
\hline \multirow[t]{2}{*}{ Tertiary education } & -0.0546 & -0.0181 & -0.139 & -0.0264 & -0.0119 \\
\hline & $(0.272)$ & $(0.0905)$ & $(0.347)$ & $(0.0661)$ & $(0.0329)$ \\
\hline \multirow[t]{2}{*}{ Household size } & -0.0101 & -0.00335 & -0.0234 & -0.00446 & -0.00254 \\
\hline & $(0.0166)$ & $(0.00550)$ & $(0.0204)$ & $(0.00388)$ & $(0.00197)$ \\
\hline \multirow[t]{2}{*}{ Farm size } & -0.0136 & -0.00451 & -0.0134 & -0.00255 & -0.00187 \\
\hline & $(0.0166)$ & $(0.00552)$ & $(0.0204)$ & $(0.00389)$ & $(0.00200)$ \\
\hline \multirow[t]{2}{*}{ Area planted } & -0.00418 & -0.00139 & 0.0558 & 0.0106 & 0.00442 \\
\hline & $(0.0316)$ & $(0.0105)$ & $(0.0364)$ & $(0.00691)$ & $(0.00358)$ \\
\hline \multicolumn{6}{|c|}{ Information access and institutional factors } \\
\hline Climate change awareness & $0.498 * * *$ & $0.166^{* * *}$ & $0.429 * * *$ & $0.0817 * * *$ & $0.0601 * * *$ \\
\hline
\end{tabular}




\begin{tabular}{|c|c|c|c|c|c|}
\hline \multirow[t]{2}{*}{ Variable } & \multicolumn{2}{|c|}{ Conservation Agriculture } & \multicolumn{2}{|c|}{$\underline{\text { Agroforestry Adoption }}$} & \multirow{2}{*}{$\begin{array}{l}\text { Joint Adoption } \\
(0.0136)\end{array}$} \\
\hline & $(0.100)$ & $(0.0325)$ & $(0.135)$ & $(0.0256)$ & \\
\hline \multirow{2}{*}{ Access to agricultural information } & 0.217 & 0.0720 & 0.0574 & 0.0109 & 0.0156 \\
\hline & $(0.137)$ & $(0.0454)$ & $(0.179)$ & $(0.0340)$ & $(0.0170)$ \\
\hline \multirow[t]{2}{*}{ Animal labour } & 0.111 & 0.0369 & 0.109 & 0.0207 & 0.0125 \\
\hline & $(0.0841)$ & $(0.0279)$ & $(0.104)$ & $(0.0198)$ & $(0.0101)$ \\
\hline \multirow[t]{2}{*}{ Agriculturalgroup membership } & $0.180^{* *}$ & $0.0599 * *$ & $0.187 *$ & $0.0357^{*}$ & $0.0235^{* *}$ \\
\hline & $(0.0846)$ & $(0.0280)$ & $(0.107)$ & $(0.0203)$ & $(0.0104)$ \\
\hline \multirow{2}{*}{ Conservation agriculture advise } & -0.0618 & -0.0205 & 0.0128 & 0.00245 & -0.000414 \\
\hline & $(0.0846)$ & $(0.0281)$ & $(0.109)$ & $(0.0207)$ & $(0.0104)$ \\
\hline \multirow[t]{2}{*}{ Access to credit } & -0.175 & -0.0582 & $0.435^{* *}$ & $0.0827 * *$ & 0.0268 \\
\hline & $(0.201)$ & $(0.0668)$ & $(0.211)$ & $(0.0401)$ & $(0.0214)$ \\
\hline \multicolumn{6}{|l|}{ Assets owned } \\
\hline \multirow{2}{*}{ Ripper } & $1.026^{* * *}$ & $0.341 * * *$ & $1.010^{* * *}$ & $0.192 * * *$ & $0.135 * * *$ \\
\hline & $(0.282)$ & $(0.0920)$ & $(0.271)$ & $(0.0510)$ & $(0.0290)$ \\
\hline \multirow[t]{2}{*}{ Radio set } & 0.0840 & 0.0279 & $0.212 *$ & $0.0404 *$ & $0.0211 * *$ \\
\hline & $(0.0855)$ & $(0.0284)$ & $(0.109)$ & $(0.0208)$ & $(0.0105)$ \\
\hline \multirow[t]{2}{*}{ Mobile phone } & -0.0251 & -0.00833 & 0.0489 & 0.00931 & 0.00176 \\
\hline & $(0.0880)$ & $(0.0292)$ & $(0.112)$ & $(0.0212)$ & $(0.0107)$ \\
\hline \multirow[t]{2}{*}{ Television set } & 0.127 & 0.0422 & 0.130 & 0.0247 & 0.0169 \\
\hline & $(0.110)$ & $(0.0365)$ & $(0.131)$ & $(0.0248)$ & $(0.0128)$ \\
\hline \multicolumn{6}{|l|}{ Geographical factors } \\
\hline \multirow[t]{2}{*}{ Choma } & $0.514 * * *$ & $0.1651^{* * *}$ & -0.005 & -0.0008 & 0.0241 \\
\hline & $(0.497)$ & $(0.0475)$ & $(0.1731)$ & $(0.0334)$ & $(0.0161)$ \\
\hline \multirow[t]{2}{*}{ Sinazongwe } & $0.39 * *$ & $0.1253 * *$ & 0.0544 & 0.0098 & 0.0244 \\
\hline & $(0.156)$ & $(0.1598)$ & $(0.1843)$ & $(0.0333)$ & $(0.0170)$ \\
\hline \multirow[t]{2}{*}{ Serenje } & $0.495 * * *$ & $0.159 * * *$ & 0.1496 & 0.0271 & $0.0368 * *$ \\
\hline & $(0.166)$ & $(0.052)$ & $(0.1861)$ & $(0.0337)$ & $(0.0175)$ \\
\hline \multirow[t]{2}{*}{ Mpika } & $0.961 * * *$ & $0.3086^{* * *}$ & $-1.283^{* * *}$ & $-0.232 * * *$ & $-0.0452^{* *}$ \\
\hline & $(0.1499)$ & $(0.0459)$ & $(0.2739)$ & $(0.0497)$ & $(0.0210)$ \\
\hline \multirow[t]{2}{*}{ Nyimba } & $0.3488 * * *$ & $0.112 * * *$ & -0.4459 & -0.0081 & 0.0138 \\
\hline & $(0.1303)$ & $(0.0415)$ & $(0.1533)$ & $(0.0278)$ & $(0.0140)$ \\
\hline \multirow[t]{2}{*}{ Constant } & \multicolumn{2}{|l|}{1.338} & \multicolumn{2}{|l|}{-0.455} & \\
\hline & \multicolumn{2}{|l|}{$(0.849)$} & \multicolumn{2}{|l|}{$(0.895)$} & \\
\hline LR Test $(\rho=0)$ & \multicolumn{2}{|l|}{$\chi^{2}(1)=17.18$} & \multicolumn{2}{|l|}{$\chi^{2}(1)=17.18$} & \\
\hline Observations & 1,231 & & 1,231 & & \\
\hline Standard errors in parentheses & & & & & \\
\hline$* * * \mathrm{p}<0.01, * * \mathrm{p}<0.05, * \mathrm{p}<0.1$ & & & & & \\
\hline
\end{tabular}

Source: (IAPRI/UNZA Climate Change and Land Use Survey (2013) Data)

\section{Conclusions and Recommendations}

Agroforestry (AF) and Conservation Agriculture (CA) are two of the best known practices that can positively contribute towards climate change mitigation and adaptation while increasing welfare among small holder farmers in Zambia (FAO, 2010). The primary objectives of this research were to determine the effect of climate 
change awareness on the adoption of both $\mathrm{AF}$ and $\mathrm{CA}$ and also to determine whether adoption of the two technologies was a jointly made decision.

Climate change awareness and its consequences was found to have had a positive effect on the adoption of AF and CA technologies singularly as well as when the adoption process was jointly decided. One of the implications of this result is that there is need to raise climate change awareness among farmers so as to increase $\mathrm{AF}$ and $\mathrm{CA}$ adoption. In addition, the decision to adopt $\mathrm{AF}$ and $\mathrm{CA}$ was found to be jointly determined by small holder farmers, therefore, the uptake of both technologies among farmers was done simultaneously.

The challenges of climate change and its effects on agriculture are not unique to Zambia but affects almost all countries on the African continent. Thus, the results obtained in this study can be extended to the rest of Africa since most countries on the continent share similar climates. This may be done by enhancing climate change awareness for improved adaptation and mitigation among farmers. However, extension to other countries with different climatic conditions may prove difficult because most agroforestry species considered under this study may not do well under such conditions.

The study therefore recommended that the government of the republic of Zambia, NGOs and other civil society organizations need to increase their efforts in raising climate change awareness among farmers throughout the country. This has the potential to significantly increase the adoption of AF and CA among the farmers. The promotion of the technologies through mass media such as the use of the radio also has the potential to enhance adoption. Furthermore the policy environment that allows for accessibility of more user friendly tools such as the ripper in the uptake of the technologies should be considered. These efforts will not only result in higher AF and CA adoption rates but also increased capacity by farmers to mitigate and adapt against the effects of climate change on agriculture production and the environment. Furthermore, adoption of AF technologies will lessen the pressure on forests by farmers as a source of fuelwood, instead, the twigs and branches from the AF planted in farmers' fields would be used as alternative fuelwood thereby saving the environment from destructive activities.

\section{Acknowledgments}

This study received financial support from the Food and Agriculture Organization (FAO) through the Msc Agricultural Economics Scholarship of the first author and we greatly appreciate this support. Data for the study was obtained from IAPRI/UNZA Climate Change and Land Use Project that implemented a supplemental climate change survey in 2013 on Rural Agricultural Livelihood Survey (RALS 2012) panel sample of 1,231 households in six districts of Zambia.

All those involved in supporting the data collection process and the actual data collection including the farmers who volunteered their scarce time to answer to the questionnaires are hereby greatly acknowledged.

\section{References}

Ajayi, O. C., \& Kwesiga, F. (2003). Implications of local policies and institutions on the adoption of improved fallows in eastern Zambia. Agroforestry Systems, 59(3), 327-336.

Ajayi, O. C., Akinnifesi, F. K., Sileshi, G., \& Chakeredza, S. (2007). Adoption of Renewable Soil Fertility Replenishment Technologies in the Southern African Region: Lessons Learnt and the Way Forward. Natural Resources Forum, 31(4), 306-17.

ARPN Journal of Agricultural and Biological Science, 8 No. 1. Retrieved from https://www.arpnjournals.com/jabs/research_papers/rp_2013/jabs_0113_512.pdf

Arslan, A., \& Edward, J. T. (2009). Farmers' Subjective Valuation of Subsistence Crops: The Case of Traditional Maize in Mexico. American Journal of Agricultural Economics, 91(4), 956-72. Retrieved from http://ageconsearch.umn.edu/bitstream/44488/2/08-002.pdf

Arslan, A., Lipper, L., Asfew, S., \& Cattaneo, A. (2013). Adoption and Intensity of Adoption of Conservation Farming Practices in Zambia. Food and Agriculture Organization. ESA Working Paper No.13-01. Retrieved from http://www.fao.org/3/a-aq288e.pdf

CFU. (2007). Conservation Farming and Conservation Agriculture Handbook for Hoe Farmers in Agro-Ecological Regions I and IIa. Retrieved August 20, 2012, from http://www.fsnnetwork.org/sites/default/files/conservation_agriculture_cf_handbook _for_hoe_farmers_zambia.pdf

Ekboir J,. M. (2003). Research and Technology Policies in Innovation Systems: Zero Tillage in Brazil. Res

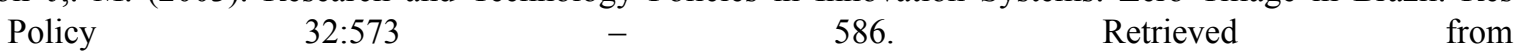
http://www.act-africa.org/news.php?com=6\&item=392\#.WUOMieuGPIU 
Erenstein, O., Sayre, K., Wall, P., Hellen, J., \& Dixon, J. (2012). Conservation Agriculture in Maize and Wheat Based Systems in the (Sub) Tropics: Lessons from Adaptation Initiatives in South Asia, Mexico, and Southern Africa. J Sustain Agric 36; $180 \quad-\quad 206$. Retrieved from http://libcatalog.cimmyt.org/download/cis/95912.pdf

FAO. (2010). Climate Smart Agriculture: Policies, Practices and Financing for Food Security, Adaptation and Mitigation. Food and Agriculture Organization, Rome. Retrieved from http://www.fao.org/fileadmin/templates/agphome/documents/climate/Climate_Smart_Agriculture_-Planet_ Under_Pressure_Conference.pdf

Franzel, S., \& Scherr, S. J. (Eds.). (2002). Trees on the Farm: Assessing the Adoption Potential of Agroforestry Practices in Africa. Wallingford, UK: CAB International. Retrieved from http://www.worldcat.org/title/trees-on-the-farm-assessing-the-adoption-potential-of-agroforestry-practices-i n-africa/oclc/55155297

Friedrich, T., Derpsch, R., \& Kassam, A. (2012). 'Global overview of the spread of Conservation Agriculture', Proceedings from the 5th World Congress on Conservation Agriculture, Brisbane, Australia, 26-30 September, 2011.

Greene, W. H. (2008). Econometric Analysis (6th ed.). New Jersey: Prentice Hall.

ICRAF. (2004). Approved Definition of Use and Adoption. Harare, Zimbabwe: ICRAF, Southern Africa.

Iskander, D. (2011). The Decision Making Process in the Adoption of Agro Forestry Technology by Smallholder Rubber Farmers in Indonesia.Published Doctoral Thesis, University of Canterbury, Christchurch, New Zealand. Retrieved from https://ir.canterbury.ac.nz/bitstream/handle/10092/5810/thesis_fulltext.pdf?sequence=1

Jamala, G.Y., Shehu, H. E., Yidau, J. J., \& Joel, L. (2013).Factors Influencing Adoption of Agro-forestry Among Smallholder Farmers in Toungo, South Eastern Adamawa State, Nigeria. J. Environ. Sci. Toxicol. Food Technol., 6(6), 66-72. $\quad$ Retrieved from http://www.iosrjournals.org/iosr-jestft/papers/vol6-issue6/I0666672.pdf?id=7731

Kabwe, G. (2010). Uptake of Agroforestry Technologies among Smallholder Farmers in Zambia. Doctoral Thesis, Lincoln University, Christchurch, Lincoln, New Zealand. Retrieved from http://ageconsearch.umn.edu/bitstream/97135/2/2009Zambian\%20Agroforestry\%20Adoption_KabweG.pdf

Keil, A., Zeller, M., \& Franzel, S. (2005). Improved Fallows in Smallholder Maize Production in Zambia: Do Initial Testers Adopt the Technology? Agroforestry Systems, 64, 225-236.

Knowler, D., \& Bradshaw, B. (2007). Farmers' Adoption of Conservation Agriculture: A Review and Synthesis of Recent Research. Food Policy, 32(1), 25-48. Retrieved from http://www.sciencedirect.com/science/article/pii/S0306-9192(06)00022-4

Kwesiga, F., \& Coe, R. (1994). The Effect of Short-Rotation Sesbania sesban Planted Fallows on Maize Yield. Forest Ecology and Management, 64(2-3), 199-208. https://doi.org/10.1016/0378-1127(94)90294-1

Maddala, G. S. (1983). Limited dependent and qualitative variables in econometrics. Cambridge University Press, Cambridge.

Mankwe, L. G. (2013). Factors Influencing Adoption of Conservation Agriculture in South Uluguru Mountains in Morogoro Region, Tanzania.Published Master's Thesis, Sokoine University, Morogoro, Tanzania.

Mavunganidze, Z., Madakadze, I. C., Mutenje, M. J., \& Nyamangara, J. (2013). Factors Affecting the Choice of Conservation Agriculture Practices Adopted by Smallholder Cotton Farmers in Zimbabwe. African Journal of Agricultural Research, 8(17), 1641-1649.

Muhammad, I., Khan, A., Inoue, M., Ashraf, M., \& Sher, H. (2011). Identifying Factors Affecting Agroforestry System in Swat, Pakistan. African Journal of Agricultural Research, 6(11), 2586-2593. Retrieved from http://www.academicjournals.org/article/article1380896456_Irshad\%2520et\%2520al.pdf

Mungatana, E., \& Kuntanshula, E. (2014). Estimating the Causal Effect of Improved Fallows on Farmer Welfare Using Robust Identification Strategies in Chongwe, Zambia. Agroforestry Syst, 87, 1229-1246.

Mwase, W., Sefasi, A., Njoloma, J., Nyoka, B. I., Manduwa, D., \& Nyaika, J. (2015). Factors Affecting Adoption of Agrofrorestry and Evergreen Agriculture in Southern Africa. Environment and natural Resources Research Journal, 5(2). http://dx.doi.org/10.5539/enrr.v5n2p148 
Neubert, S., Kömm, M., Krumsiek, A., Schulte, A., Tatge, N., \& Zeppenfeld, L. (2011). Agricultural development in a changing climate. German Development Institute (DIE), Bonn, Germany. Retrieved from https://www.files.ethz.ch/isn/128010/Studies\%2057.pdf

Nyambose, W., \& Jumbe, B. L. (2013). Does Conservation Agriculture Enhance Household Food Security? Evidence from Smallholder Farmers in Nkhotakota in Malawi. Invited paper presented at the $4^{\text {th }}$ International Conference of the African Association of Agricultural Economists, September 22-25, 2013, Hammamet, Tunisia. Retrieved from http://purl.umn.edu/160528

Peterson, J. S. (1999). KubweletzaNthaka: Ethnographic Decision Trees and Improved Fallows in the Eastern Province of Zambia (Report to the University of Florida's 'Gender and Soil Fertility in Africa' Soils Management Collaboration Research Support Program (CRSP) and the International Centre for Research on Agroforestry): University of Florida and ICRAF.

Phiri, D., Franzel, S., Mafongoya, P. L., Jere, I., Katanga, R., \& Phiri, S. (2004). Who is Using the New Technology? The Association of Wealth Status and Gender with the Planting of Improved Tree Fallows in Eastern Province, Zambia. Agricultural Systems, 79(2), 131-144.

Rogers, E. M. (1983). Diffusion of Innovations (3rd ed.). New York: The Free Press.

Rogers, E. M. (2003). Diffusion of Innovations (5th ed.). New York: The Free Press.

Sechrest, L., Stewart, M., \& Stickle, T. (1998, October). Factors Affecting the Adoption and Impact of CGIAR innovations: A synthesis of findings (A report to the Impact Assessment and Evaluation Group (IAEG)): University of Arizona. Retrieved From http://hdl.handle.net/10947/603

Smale, M., Just, R., \& Leathers, H. (1994). Land Allocation in HYV* Adoption Models: An Investigation of Alternative Explanations. American Journal of AgriculturalEconomics, 76, 535-546.

Umar, B. B., Aune, J. B., Johnsen, F. H., \& Obed, L. I. (2011). Options for Improving Smallholder Conservation Agriculture in Zambia. Journal of Agricultural Science, 3(3), 50-62. https://doi.org/10.5539/jas.v3n3p50

Valipour, M. (2012). Number of Required Observation Data for Rainfall Forecasting According to the Climate Conditions. University of Tehran, Pakdasht, Tehran, Iran. American journal of Scientific Research, 74, $79-86$.

Valipour, M. (2013). Evolution of Irrigation-Equipped Areas as Share of Cultivated Areas. University of Tehran, Pakdasht, Tehran, Iran. Irrigation and Drainage Systems Engineering. http://dx.doi.org/10.4172/2168-9768.1000e114

Valipour, M. (2013). Increasing Irrigation Efficiency by Management Strategies: Cutback and Surge Irrigation. University of Tehran, Pakdasht, Tehran, Iran. Irrigation and Drainage Systems Engineering.

Valipour, M. (2015). Assessment of Important Factors for Water Resources Management in European Agriculture. University of Tehran, Pakdasht, Tehran, Iran. Journal of Water Resource and Hydraulic Engineering, 4; 174 - 180. Retrieved from http://www.academicpub.org/DownLoad Paper.aspx?paperid=16749

Valipour, M. (2017). Global experience on irrigation management under different scenarios. University of Tehran, Pakdasht, Tehran, Iran. Journal of Water and Land Development, 32, 95-102.

Valipour, M., \& Montazar, A. A. (2012). An Evaluation of SWDC and WinSRFR Models to Optimize of Infiltration Parameters in Furrow Irrigation. University of Tehran, Pakdasht, Tehran, Iran. Journal of Water and Land Development, 32, 128-169. Retrieved from http://www.eurojournals.com/ajsr.htm

Valipour, M., Mousavi, S. M., Valipour, R., \& Rezaei, E. (2012). A New Approach for Environmental Crises and its Solutions by Computer Modeling. International Congress on Environmental Crises and its Solutions. Retrieved from https://www.civilica.com/EnPaper--ICECS01_005.html

Wall, P. C. (2007). Tailoring Conservation Agriculture to the Needs of Small Farmers In Developing Countries. Journal of Crop Improvement, 19, 137-155. Retrieved from http://repository.cimmyt.org/xmlui/handle/10883/1496

\section{Copyrights}

Copyright for this article is retained by the author(s), with first publication rights granted to the journal.

This is an open-access article distributed under the terms and conditions of the Creative Commons Attribution license (http://creativecommons.org/licenses/by/4.0/). 